\title{
On the 6oth Anniversary of the Hart-Fuller Debate
}

\author{
Sobre el 60 aniversário del debate Hart-Fuller
}

\author{
Angela VIDAL GANDRA MARTINS \\ CEU Law School (Brazil) \\ angela@gandramartins.adv.br
}

RECIBIDO: 07/05/2018/ACEPTADO: 20/06/2018

\begin{abstract}
On the 6oth Anniversary of the storied HartFuller Debate, we would like to briefly revisit it to highlight some of its concerns and discussions in order to demonstrate how vivid they still are and may serve as a path to the Rule of Law, concluding on the importance of promoting fruitful argumentation on essential issues in Jurisprudence to enlighten the practice of Law.
\end{abstract}

Keywords: Hart-Fuller debate; Philosophy of Law; morality; positivism; rule of law.
Resumen: Con ocasión del sesenta aniversario del importante debate Hart-Fuller, volvemos a él para destacar algunos de sus principales aspectos buscando mostrar su actualidad y su capacidad de servir para la consolidación del Estado de Derecho. Concluimos enfatizando la importancia para iluminar la práctica jurídica de fomentar discusiones fecundas en cuestiones esenciales de la Filosofía del Derecho.

Palabras clave: debate Hart-Fuller; Filosofía del Derecho; moralidad; positivismo; Estado Democrático de Derecho.

\section{INTRODUCTION}

Out of the 'witches' cauldron'?

Nicola Lacey

J

ust over sixty years ago, Harvard Law School provided the scenario for a debate between two influential legal theorists from the anglo-saxon world, which turned to be the so called «Hart-Fuller Debate» ${ }^{1}$.

Lon Fuller, Professor of General Jurisprudence at Harvard, invited Herbert Hart, Professor of Jurisprudence at Oxford and «holder of England's most prestigious position in Legal Philosophy» ${ }^{2}$ at that time, to give the Law School's Annual Holmes Lecture. Professor Hart took the opportunity to enunciate his emerging theory of positivism -not exactly formalist-, though invited by Fuller, who, in his turn, was «not infrequently accused of stirring

1 Lacey, N., «Out of the Witches Cauldron? Reinterpreting the Context and Reassessing the Significance of the Hart-Fuller Debate», in P. Cane (ed.), The Hart-Fuller Debate in the Twenty-First Century, Hart-Publishing, , Oxford. 2011, p. 1.

$2 \ll(. .$.$) but with only a handful of articles though», in ibid., p. 5-6.$ 
the «witches'cauldron' of irracionalist natural law theory ${ }^{3} »$. That year at Harvard changed Hart's life, «in the stimulating publishing-oriented atmosphere of a top American law school ${ }^{4} \gg$ and projected him to become a significant theorist in the Jurisprudence world.

On the other side, Lon Fuller, the unforgettable author of «The Case of Speluncean Explorers ${ }^{5} »-$ and not exactly a «nice new englander with some quite original ideas ${ }^{6} »$, as Hart once expressed -, was born in Texas and had a very special concern on decision making processes since his childhood ${ }^{7}$. He studied Economics and Law; had a strong social scientific perception, and was a self taught in Philosophy and Anthropology ${ }^{8}$. During his life time, he has been an arbitrator - what he would refer to as «solving problems» more than «dispute resolutions» - and actively engaged in institution-building9. Since 1926 he headed straight to academic life and from 1948 to his retirement in 1972, he held the Carter Chair (formerly Roscoe Pound) at Harvard Law School ${ }^{10}$ with a special involvement in ensuring adequate materials for the study of Jurisprudence ${ }^{11} \gg$. Fuller was a popular teacher, «vigorous yet kind$1 y^{12} \gg$. As Griswold put: «He set high standards, but terror was never an element in his method $\gg^{13}$. Indeed, he was perplexed with Hart's exposition, for secular Natural Law was the basis of his own theory, since «his deep interest in the significance of institutions was not a separate agenda, but rather found consistent expression in his explicitly jurisprudential work» ${ }^{14}$.

Their exchange has been published in the Harvard Law Review in 1958 and the legacy, departing from the concerns raised after the II World War on the validity of legal systems, are still enlightening Philosophy of Law to understand the role of forms and content in making a Rule of Law possible

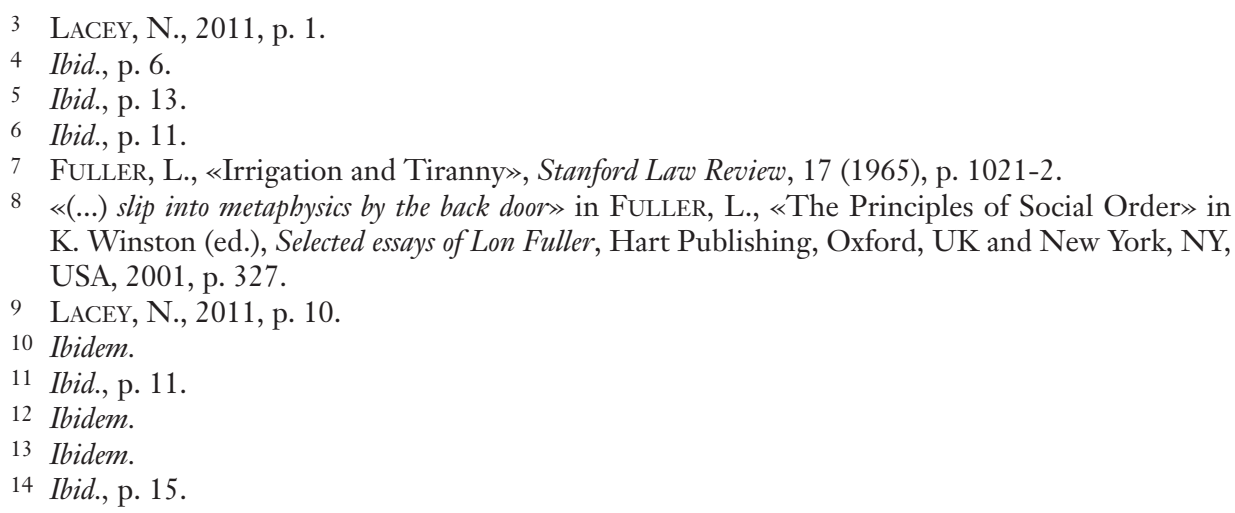


departing from the discussion of the separability of law and morality, namely, affirming the power of Law itself, stripped of moral normative sense, and the problems it does generate when legal language is emptied of a reasonable criterion based on anthropological evidences.

Therefore, although we intend to briefly present both positions with fidelity to the ideas conveyed in and from the debate, we also target to honor Fuller, for the coherence of his thought and concern on legal education, so that future lawyers and judges could really become instruments of justice. In fact, through his writings, gathered in the last chapter of «The Principles of Social Order» edited by Kenneth Winston ${ }^{15}$ and named «Legal Philosophy, Legal Education and The Practice of Law», he demonstrated how essential is helping Law students to reflect, promoting a productive thinking and a solid legal education towards a fair and just practice of Law.

\section{The Hart - Fuller Debate}

His argument is better than his. Leo Strauss ${ }^{16}$

The exchange between Lon Fuller and H.L.A. Hart was chosen to be the central theme of a colloquium held at the Australian National University in 2008, celebrating the 50th Anniversary of the debate ${ }^{17}$. In 2011, Peter Cane reunited and published the presentations. Some important Jurisprudence scholars such as Jeremy Waldron, Kristen Rundle, Gerald Postema, along with others, revisited and reinterpreted the argumentation. As Nicola Lacey stated in this publication: even a search in internet, would show Hart's Concept of Law with 91.000 against Fuller's Morality of Law with $49.000^{18}$. Thus, rethinking the debate happened to be an opportunity to give the proper recognition to each position, which only the passage of time can define and prove.

15 FULLER, L., 2001.

16 Refering to Fuller's in the debate. Summers, R., Lon L. Fuller, Stanford University, Stanford, 1984, p. 4.

17 Cane, P. (ed.), The Hart-Fuller Debate in the Twenty-First Century, Hart-Publishing, Oxford, 2011, Preface.

18 LACEY, N., 2011, p. 2. 
The main discussion departing from Hart's Lecture at Harvard was the separation of law and morals. This question was raised by the possibility of Nazi law being qualified as such, namely, a legal system, based on the enacted statutes and a rule of recognition, so called by Hart as an imperative command formally legitimated, since in his perspective, legal rights and moral rights are not related. In fact, in 1951, a german woman was convicted of illegally depriving her husband from freedom, although she argued she had not perpetrated a crime while acting according with the law of her country at that time.

Hart's sophisticated theory on legal positivism within the framework of analytic Philosophy, was launched right there, during his lecture, although it was only the beginning of a broader chain of ideas and consequences. Linguistic arose as a special tool to interpret law, combined with the jurisprudential tradition to solve cases that go beyond the core - cases covered by the statutes - and reach what Hart labeled penumbra. On the other hand, he also tried to balance obedience to Law - departing from John Austin's theory, with a sort of acceptance based on the rule of recognition, and not only in coercion, since he rejected Kelsen's positivism - although influenced by him -, mainly on sanctions. In Hart's view, this obedience would not be founded in the idea of justice or morality. In his proposal, he offers a distinction between primary and secondary rules, where those govern conduct, while the second allow creation, modification or extinction of primary rules through the rule of recognition. In this regard, there are two perspectives: the external aspect, namely, the tendency of observance of rules with regularity, and the internal point of view, which provide the critical reflective attitude. The normative quality of law will depend precisely in this turning point. But, all things considered, Hart's argues that the question of what is Law must be separated from the question of whether it is moral or just. What matters is the Law as it is, and not as it should be, and the legal system as functioning effectively, though neither just or moral. Its content would not be a question for the Law.

In this sense, Law's validity is independent and the legislator's role is peripheral and insert in a more complex structure. In fact, primary rules, operated by officials entrusted by secondary rules, will have to be guided by the rule of recognition which is the criteria of the validity of law. Therefore, a legal system would be the union of primary and secondary rules, with the endorsement of the rule of recognition.

On the other side of the debate, Fuller firmly sustained that law and morality could not be so neat distinguished and that calling the Nazi system «legal» and its rules «law» was a false description of what they were in fact, namely, in- 
struments of an arbitrary and tyrannical regime. Thus, he tried to demonstrate through his named «inner morality» that Law is not a neutral concept and must be founded in some moral procedural requirements ${ }^{19}$ such as clarity, non-retroactivity, publicity, generality, reciprocity, etc., respecting human agency and its constitutive freedom. Therefore, Law would motivate human conduct through rational purposes and promote communication, initiative and responsibility towards the social order as a corollary. As Professor Rundle affirmed, based on Fuller's assumption that to be a legal subject is not merely to be a member of a subservient populace ready to do what they are told to $\mathrm{do}^{20}$ :

For Fuller, there can be no meaningful concept of law that does not include a meaningful limitation of the lawgiver's power in favor of the agency of the legal subject. ${ }^{21}$

Besides, while fighting Hart's «rule of recognition», Fuller underlines its incapacity of being a mirror of people's acceptance, since Hitler completely manipulated Nazi law, identifying it with his own dominatrix will and inconsistent with the constitutional system, as well. Indeed, for Fuller, Law not only should protect the agency but presupposes it in its origin ${ }^{22}$. In his viewpoint, the essential issue of Nazi law would not be the atrocities committed through its commands, but mainly because formerly, its procedure did not treat people - Jews! - as free and responsible. Thus, Fuller wanted to denote that the binding power of Law doesn't come from the strength of the significance of its words but from its inner morality ${ }^{23}$, where we also find reciprocity in applying and obeying the Law. Hence, if at that time Nazi law had been previously submitted to the eight desiderata required through the procedural morality of Law, the damaging content would never have been able to survive ${ }^{24}$.

Let us see how Fuller presents his statements.

19 RUNDLE, K., «The impossibility of an exterminatory legality: law and the holocaust», in University of Toronto Law fournal, n. 59 (2009).

20 Undated and untitled document. The papers of Lon L. Fuller, Harvard Law School Library, Box 12 , Folder 1 (notes for «Reply to Critics»).

21 RundLe, K., Forms Liberate. Reclaiming the furisprudence of Lon Fuller, Hart Publishing, Oxford, 2012 , p. 2.

22 RosLer, A., You can not go grossly morally wrong with Law. Can you? Draft for Furisprudence, Buenos Aires, 2012, p. 6.

23 Martins, A. V. G. DA S., A moralidade do Direito como Condição de Liberdade em Lon Fuller, $2^{\text {a }}$ ed., Lex/Magister, Porto Alegre, 2017, p. 117.

24 Ibid., p. 118. 


\section{Form, SUbSTANCE AND THE Rule OF LAW}

Forms liberate

Fuller

Maybe a dream come true for some positivists would be simply oppose form to substance in Law and decide cases literally. In fact, the core of the Hart-Fuller Debate is form against moral content. Positivism tends to formalism, although Hart is aware of the limits of language ${ }^{25}$, chiefly in hard cases. In this sense, he opposes the noble dream - «for every conceivable case there is some solution which is already law before he decides the case and which awaits its discovery» ${ }^{26}$ - and the nightmare, where the decisions depend on the political and economic moment and are performed by judges, as we find in American realism. Considering his double perspective, Hart prefers to be attached to norms then to judges.

On the other hand, Fuller tries to demonstrate how form and substance can coexist harmonically, through rational and reasonable purposes, capable of «subjecting the human conduct to the governance of rules ${ }^{27}$, when protected by an internal procedural morality expressed in eight desiderata ${ }^{28}$ :

1. Generality: implies primarily the establishment of rules - «there must be rules» - departing from rational patterns (reasoned generality) and directed to all citizens in general without distinction, also avoiding ad hoc decisions and securing the neutrality of courts ${ }^{29}$. This desideratum guarantees the unity and integrity of the system, protecting it from casuism as well.

2. Promulgation: the rules must be known through their publication though its legality doesn't depend simply on it - so that citizens can orient and calculate the consequences of their conduct ${ }^{30}$. The publicity also helps not to evoke the ignorance of the Law.

25 Tavares, A. R.; Osmo, C., «Interpretação Jurídica em Hart e Kelsen: Uma postura (Anti) Realista?», in Teoria do Direito Neoconstitucional ou Reconstrução do Positivismo Furídico, Método, São Paulo, 2008, p. 131.

26 Ibid., p. 137 et seq.

27 FULLER, L., The Morality of Law, Fawcett, New York, 1964, p. 110.

28 Ibid., p. 59 et seq.

29 Fuller, L., «A Reply to critics», in The Morality of Law Yale University, New Haven, 1969, p. 109.

30 Ibid., p. 51. 
3. Prospectivity: rules must not be retroactive. In fact, to direct today's behavior with laws edited tomorrow is an empty act. It is not simply a bad Law. It is not Law at all ${ }^{31}$. Overrule would be an exemption and always in a helpful and positive way $^{32}$. This desideratum has a deep connection with the problem of due process of law, mainly in Criminal Law, as accepted by the Nazi State, what proves its anti-juridicity. For Fuller, prospectivity is not only an aspiration of perfection but a clear way to avoid and recognize the most obvious indecencies ${ }^{33}$.

4. Clarity: The responsibilities involved in the demand must be clear. This is one of the most desired ingredients of juridicity. We should not express Law in an unintelligible way: an obscured legislation turns legality untenable and demands continuous revisions, undermining the legal system ${ }^{34}$.

5. Consistency: laws can't demand contradictory actions. Lack of coherence within the legal system and incompatibilities - things that not go together or not go together well - must be avoided ${ }^{35}$.

6. Possibility: laws can't require the impossible or unreasonable. This requirement is rooted in an intern principle of obedience, drafting guidelines to human efforts - not superhuman - and avoiding exploration, manipulation, pernicious acts, etc. ${ }^{36}$

7. Constancy: rules must remain relatively stable through time. Law changes should not be frequent. Its inconstancy would certainly cause problems with retroactivity ${ }^{37}$. Thus, in Professor Luis Fernando Barzotto's words, Law can accomplish its function as an instrument not of transformation but of social preservation ${ }^{38}$.

8. Congruence: there must be compliance and harmony between official action and declared rules. This desideratum promotes reciprocity, which is crucial for a healthy legal system. It is hard to obey something that are is not obeyed by the person responsible for the command. In some way, trust on the system is based in this requirement ${ }^{39}$. On the other hand, congruence relies

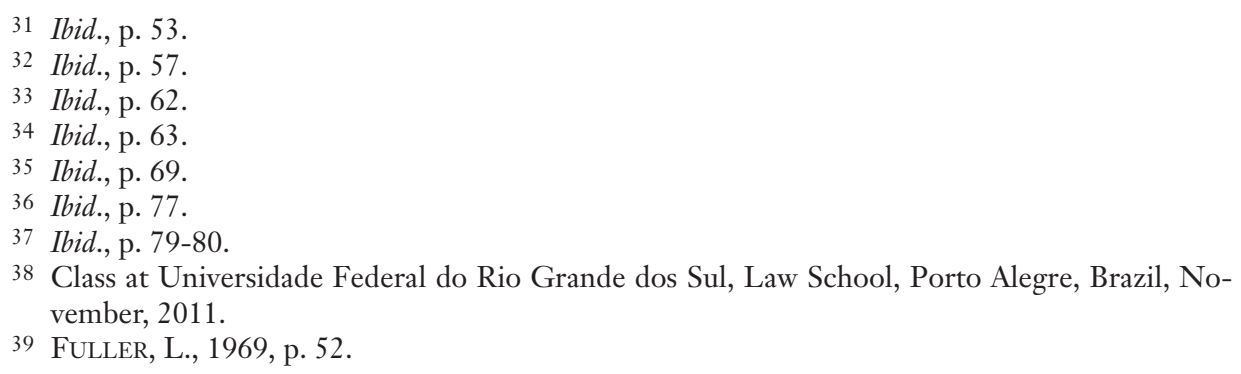


on the right interpretation of Law, which respects its intention and purpose ${ }^{40}$ in a detached way in order to correctly apply $\mathrm{it}^{41}$.

In fact, these moral procedural requirements respect form and content of Law as well:

Some identify his theory with the skeleton of the rule of law. The «originalists» fulfilled the body with constitutional content. But in Fuller's case, the analogy would refer to the health of the organism, stating that it would be easier to heal a flu through the procedural morality than a cancer perverting the whole system, through a discussion on substance, allowing judges to decide beyond Law. Robert Summers expresses the bound between form and the rule of law: Fuller attested the important relation between dedicatedly pursuing procedural purposes in a determined system and the quality of the substantive objectives achieved. Specifically, in his point of view, a healthy Rule of Law generates a sound, or at least harmless substantive law, or, as Fuller synthetizes: If we do things the right way, we are likely to do the right thing ${ }^{42}$

Within his theory, Fuller corroborates that a Rule of Law can't be reduced to norms literally interpreted through its purpose and applied, its legality supposed. He demonstrates that there is a pattern of moral commitment - though procedural, in fact, anthropological and secular - that sustains it by respecting human nature as:

a) rational - citizens should be guided by the purpose of the Law for a «wholehearted and understanding acceptance» ${ }^{43}$;

b) relational - the goal of the Law is to secure good social and economic relations (workable arrangements) in the Community (shared commitment) ${ }^{44}$;

40 Private intentions are irrelevant: «Speaking of the Statute of Frauds, Lord Nottingham Said in Ash v. Abdy, 3 Swanston 664 (1678), «I had some reason to know the meaning of this law; for it had its first rise from me.». Cf. «If Lord Nottingham drew it, he was the less qualified to construe it, the author of an act considering more what he privately intended than the meaning he has expressed». Campbell's Lives of the Lord Chancellors of England, 3 (3rd ed., 1848), 423 in Fuller, L., 1969, p. 86.

41 (...) not according to judges's fantasies (...) but with the totality of the legal system. In FULLER, L., 1969, p. 82.

42 Martins, A. V. G. DA S., «Fundamentos Procedimentais do Estado Democrático de Direito em Lon Fuller», Anuario de Derecho Constitucional Latino-Americano, año XX (2014), p. 697.

43 Winston, K., 2001, p. 6.

44 Fuller, L., «Eunomics: The Theory of Good Order and Workable Social Arrangements», in Winston, K., 2001, p. 61 and seq. and 82 et seq. 
c) free - the human being has a constitutive right to self-direction, in a positive way ${ }^{45}$ and Law should promote it;

d) responsible - not only in facing the consequences of their choices, but also in the sense of carrying about the development of society ${ }^{46}$.

As a matter of fact, Fuller brings good News to Jurisprudence. Betting on nature, without overestimating it, but taking it as it is - the way things are ${ }^{47}$ - he connected realism, not through skepticism towards rules or men, but in an optimistic style ${ }^{48}$, conceiving Law as a collective project of citizens, where «affinities between legal rules and informal social expectations must close ${ }^{49}$. That is why Hitler's commandments were so repulsive to Fuller.

Indeed, if the eight requirements, based on Fuller's anthropological conception, could have judged Nazi Law in its very beginning, we would never have gotten to its disastrous and anti-human consequences. But in some way, the debate remains.

\section{The Debate IN THE 21ST CENTURY}

The plan was to identify themes that lay on or below the surface of the debate and to rethink them in the light of social, political and intellectual developments in the past 50 years. Peter Cane ${ }^{50}$

A deep debate in Jurisprudence may always be a light for the future: «a point of departure and inspiration ${ }^{51} \gg$. Among other discussions on this significant debate, we found the effort of Peter Cane in gathering different topics rooted in its assumptions, such as Human Rights, International Criminal Law, Pluralism, Normative Social Behavior, Legal Reasoning and Law making, Law and Politics, Instrumentalism, etc.

This specific study is a sample of how Philosophy of Law goes back and forth, deepening the legal thought not only with historical interest but as a

\footnotetext{
45 Winston, K., 2001, p. 19; 318-319;321, 323-28, etc.

46 Ibid., p. 207 et seq.

47 Fuller, L., The Anatomy of Law. Wetsport: Greenwood, 1987, p. 53.

48 Ibid., On Teaching Law. Cambridge: Harvard Law School Repository, 1950, p. 39.

49 Ibidem.

50 CANE, P., 2011, Preface.

51 Ibidem.
} 
«springboard», through lens which can view further to enlighten new issues and contexts, with tangible conclusions for the practice of Law, as Cane states:

In my opinion, they demonstrate that this debate between two of the twentieth century's greatest legal theorists continues to present a rich, and by no means exhausted, seam of jurisprudential ideas waiting to be mined in the years to come. ${ }^{52}$

In fact, the debate brought out lights, for instance, to implement an International Procedural Right; to the importance of global visibility in Law; to detailed issues on the Rule of Law applied; on concrete adjudication and relationship between systems; on deep questions on interpretation; on the rationality of commitments and even to honesty as a basis for justice. Indeed, Fuller's inner Morality - mainly configured through the debate - disclosed the problems of positivism and American realism, offering a solution that can make Law possible ${ }^{53}$ and promoting positive citizen's interaction through the accomplishment of «my word is my bound ${ }^{54} \gg$ in both sides, as well.

Even though the debate has served as a source of reflection to many areas, we would like to focus on a specific issue, departing from what we name - mainly in Latin America-, neoconstitutionalism. The Rule of Law scheduled in the eight requirements has been the topic of some conferences in a past few years, since almost none of them are respected in the populist regimes established in this continent, where the worst sample would be Venezuela.

We also quote the experience of Brazil, where Fuller's theory was brought in books and papers ${ }^{55}$ to reflect on the steps to the Rule of Law. Indeed, the country is hardly and slowly heading to the so desired «Estado Democrático de Direito», with the impeachment of a President, the «Operação Lava Jato» against corruption and the prison of another popular president recently convicted. The desiderata could show the entangled confusion between the

52 Ibidem.

53 Fuller, L., 1964, p.46 et seq.

54 Pettit, P. «How Norms Become Normative», in Cane, P., 2011, p. 246.

55 Jardim, F., Teoria Interacionista do Direito: PL 7448/2017 merece ser sancionado, <https://www. jota.info/opiniao-e-analise/artigos/teoria-interacionista-do-direito-23042018>, April 24, 2018 (visited May 3, 2018); Costa, M.; e Martins, I. G., A importância do Direito de Defesa para a democracia e a cidadania, OAB, São Paulo, 2018. MARTins, A. V. G. DA S., «Fundamentos do Estado Democrático», in Folha de São Paulo (August 25, 2018); and ID., «Racionalidade Jurídica à moda da Casa», in $O$ Estado de São Paulo (May 1, 2018). 
Executive, Legislative and Judiciary powers - a vaccum of congruence -; lack of generality in applying rules with selectivity; ignorance cultivated through ideology in collusion with media; attempts to apply laws in a retroactive way; lack of proportionality and arbitrariness in penalizing - or not - convicted politicians; systemic inconsistency and incoherence in adjudication and chiefly a complete lack of correspondence to the citizen's legal expectations based in an anti-ethical behavior due to political interests.

As we can see, even in a crisis, the inner morality can help to figure out how to overcome it, still being a light to guide scholars and operators of Law. Indeed, an important legacy of the Hart-Fuller Debate.

\section{Conclusion}

They exchanged views about plans for the wider dissemination of jurisprudential ideas in forms accessible to students. Nicola Lacey

This brief essay was presented during a very interesting and fruitful Seminar held at the University of Navarre in January 2018 on «The Future of Philosophy of Law». In fact, it endorsed our conclusion towards a reflection on the importance of promoting productive thinking in academic life so that Law students can go beyond in the role they will play as «architects of social structures ${ }^{56} \gg$, as Fuller called Law operators:

In sketching this idea of mission, Fuller opposes what he calls the litigational conception of a lawyer's competence currently dominant in legal education. According to this conception, which was a major legacy of legal realism, a lawyer's expertise lies in the ability to predict and influence the exercise of state power, especially in courtrooms. Law professors contribute to the development of this expertise by making students knowledgeable about the behavior patterns of judges. But Fuller rejects this conception, primarily because it turns lawyers into masters of technique without regard to the ends they serve ${ }^{57}$.

\footnotetext{
56 Fuller, L., 2001, p. 285.
}

57 Winston, K., 2001. 
Indeed, Fuller had a special concern in legal education and a real interest in his students, aiming to be not a «wet blanket», but a «spark plug» by fostering a «training appropriate to their vocation ${ }^{58}$. This was the goal of the Holmes Lecture which originated the Hart-Fuller Debate: give them a deeper sense, not only methods and techniques; face reasons and whys and ask for the nature of legal problems to think like lawyers ${ }^{59}$ in order to contribute to the efficient attainment of social goals and human improvement.

The Hart-Fuller Debate is a treasure of Jurisprudence, from where our needy century, thirsty of justice, keeps on bringing out its jewels to light. May we also promote healthy discussions based on deep study to prepare new instruments of justice - our pupils - to be able to build a fairer society. As Fuller stated, «injustices are made with elbows not with wrists ${ }^{60} \gg$.

58 Ibid., p. 294.

59 FULler, L., 1950, p. 37 and 41.

60 Winston, K. «Legislators and Liberty», Law and Philosphy, v. 13, n. 3 (1994), p. 394-395. 